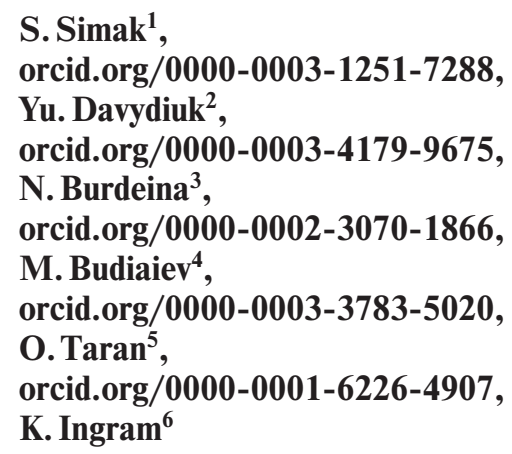

1 - V.I. Vernadsky Taurida National University, Kyiv, Ukraine, e-mail: sergii.simak@gmail.com

2 - Zhytomyr Polytechnic State University, Zhytomyr, Ukraine

3 - Odesa Military Academy, Odesa, Ukraine

4 - Kyiv national economic university named after Vadym Hetman, Kyiv, Ukraine

5 - Kharkiv National Agrarian University named after V.V. Dokuchaev, Kharkiv, Ukraine

6 - Mykolas Romeris University, Vilnius, Lithuania

\title{
COMPREHENSIVE ASSESSMENT OF THE ECONOMIC CONSEQUENCES OF THE COVID-19 PANDEMIC
}

Purpose. To analyse and summarize some aspects of the negative impact of coronavirus infection Covid-19 and to provide a comprehensive assessment of the consequences of the pandemic on the world economy and the economy of Ukraine in particular.

Methodology. The study used a comprehensive analytical assessment of the impact of the pandemic on the world economy, based on reports and prognostic assessments of well-known scientists and experts, international financial and credit rating organizations, as well as personal observations of the authors.

Findings. The obtained results testify the aggravation of the economic situation in the world and in Ukraine in particular. In a short time (six months), world GDP decreased by almost $4 \%$, and in such major countries as the United States - by $9.1 \%$, the EU - by $14.4 \%$, Ukraine - by $11.4 \%$. This is evidenced by declining industrial production, declining productivity, bankruptcy and liquidation of small, micro and individual entrepreneur enterprises, declining household incomes and rising unemployment. There is a situation when governments do not focus on the development of the internal market, but increase the amount of credit resources taken to cover the balance sheet deficit. Incentives implemented in most countries around the world to support the business environment and the population show that this level reaches 10-25\% of GDP. At the same time, the current fund in Ukraine was only $1.5 \%$, which is clearly insufficient. The introduction of strict restrictions in Ukraine in 5 stages has led to the closure of many small businesses and individual entrepreneurs, which reduces revenues to budgets at various levels. Thus, the spheres most affected by quarantine measures were arts, sports, entertainment and recreation (almost $80 \%$ drop in income), research and development $(73 \%)$ forestry and logging $(67 \%)$, the least affected - financial and insurance activities (only $5.4 \%$ ). Thus, the projections developed by leading international and credit rating institutions indicate the disappointing consequences for the world economy by the end of 2020, after which a gradual thawing will begin. However, it is unclear how the economic recovery will continue if quarantine measures continue. This may be evidence of erroneous forecasts and the deepening recession in the world economy.

Originality. We propose to conduct a comprehensive analysis of the main indicators of the state and development of the economic situation using the following indicators: annual GDP growth, ratio of public debt to GDP, unemployment, consumer price index, annual inflation, industrial production, business confidence and consumer confidence index. The set of these indicators reflects the trend of economic development in a crisis situation.

Practical value. This technique can be used by specialists of the Ministry of Economic Development, Trade and Agriculture of Ukraine, research institutions and institutes, individual scientists as a basis for monitoring the situation in the country and regions during the economic crisis.

Keywords: world economy, economy of Ukraine, quarantine measures, Covid-19 pandemic, economic consequences, recession

Introduction. The emergence and spread of the new Covid-19 disease, which is based on the coronavirus was declared a pandemic by the WHO on March 11, 2020. However, the situation that has arisen raises many doubts about the need for tough measures in the national economies of the world (with the exception of Sweden and Belarus). According to the WHO, the new virus has spread to almost the entire world, which has led to the adoption of quarantine measures in many countries. Quarantine measures, for a period specified by the presidents and governments of such countries, made provisions for the closure of socio-cultural and educational institutions, trade enterprises (excluding food, medical and chemical products), manufacturing enterprises and other businesses.

Prior to the pandemic, the world's largest economy, namely the United States, featured good economic growth and the lowest unemployment rate in the country's 50 years of independence. Currently, this figure reaches 45 million people (from $3.6 \%$ in 2019 to $13.7 \%$ in 2020 of the total working population) and continues to grow. Despite a large social package (initially $\$ 200$ per person and child and up to $\$ 600$ )

(C) Simak S., Davydiuk Yu., Burdeina N., Budiaiev M., Taran O., Ingram K., 2020 approved by the President and the US Senate, the family budget is clearly insufficient to cover all necessary expenses. The situation is not the best in Ukraine either, where quarantine measures and population losses not only lack compensation, but, on the contrary, are becoming more severe. The population not only fails to receive a salary, but also cannot provide full support for their own family, and cover utility costs. The President and the Government of the country adopt and approve new laws, regulations and normative legal acts aimed at increasing utility bills, introducing new taxes and fees, as there is nothing to fill the country's budget with. Prices for food and medicine have risen significantly. This also happens due to the forecasts of the WTO and experts on the crop failure of grain and other crops, vegetables and fruits.

Thus, the situation that has arisen and its future socioeconomic consequences not only in individual countries but also around the world need to be studied in detail.

Literature review. The issue of the negative trend of economic development is studied by scientists and specialists from different countries. Many of them support the decisions of their governments to impose strict quarantine measures to contain the spread of the virus, others evaluate them negatively, because this is a restriction of social freedoms and the cause 
of economic decline. The level of incomes of individuals and legal entities, revenues to the budgets of various levels are decreasing, utility payments, the country's debt to foreign or international financial organizations are increasing.

The closure of national borders and the division of countries according to the levels of risk of the disease have led to the closure of air, rail and road connections with the EU and other countries.

In 2020, there was a huge drop in GDP. Thus, the NBU forecasts a $5 \%$ drop in Ukraine's GDP [1], in France - by $5.8 \%$, Spain - by $4.1 \%$, in the EU as a whole $-7 \%$, the United States $-5.6 \%$, the United Kingdom $-6.3 \%$, and a global decline will reach $3.9 \%$ [2].

According to Neshodovsky [3], most countries have directed their efforts in the following areas - the liquidity of enterprises and the promotion of effective demand.

Myronenko-Shulgan [4] adheres to the point that under the quarantine conditions small and micro enterprises need the biggest support.

According to Nitsenko [5], during the year of the presidency of President V. Zelensky, the economic situation deteriorated significantly, which led to a systemic economic crisis within the country. This is confirmed by the fact that public debt increased by $17 \%$ within almost one year, by almost $\$ 8.5$ billion, which is evidence of the low level of qualifications and competencies of the new presidential team.

In the outlined conditions, according to Zalizko, et al. [6], the problem of economic security of the country needs to be solved immediately. They propose to introduce additional indicators and sub-indices for a more complete analysis of the epidemiological situation in the country.

Thus, on March 26 and April 21, the US President and the Senate approved programs to support the country's economy and population to prevent an economic downturn totaling $\$ 2.68$ trillion. As a result, personal income of households in the second quarter of 2020 increased by $32.6 \%$, despite the fact that this indicator in relation to GDP decreased by a third [7]. The United Kingdom has adopted a \$ 39 billion coronavirus program, one-fifth of which is aimed to support the most vulnerable and self-employed people whose incomes are be- low average [8]. A similar Fund [9] has also been established in Ukraine, with a total amount of almost UAH 66 billion [10] to combat the consequences of the problem.

Unsolved aspects of the problem. The economic situation in which most countries of the world appeared to be, and Ukraine in particular, requires a detailed study on the factors that have led to it and the definition of ways to eliminate them.

The purpose of the article is to assess past, current and projected values of economic development in a pandemic.

Methods. The research is based on the use of various individual elements and systematic analysis of data in general. The study was based on expert opinions and the results of surveys. Forecasts of international financial and investment credit rating organizations were used to identify future trends in economic development.

Results. Economic consequences: worldwide scale. The world's largest and most developed markets have not escaped the deepening economic problems caused by the Covid-19 pandemic. Currently, the world economy is experiencing the largest decline in the last 50 years, as evidenced by the following data (Table 1) [11].

The destruction of the world economy has revealed colossal local problems. The effectiveness of measures aimed at supporting the functioning of economies in the middle of the countries has not been positively reflected in the results of quarantine measures. The result is not only a decline in incomes, bankruptcy (Table 2) [11, 12], but the decline in GDP, the largest in decades.

Experts from the Center for Aviation cite data that by the end of May most of the world's airlines will go bankrupt [13]. That is true, because the national borders of most countries are closed, tourist flows have stopped.

Surveys conducted by the Union of Ukrainian Entrepreneurs showed that only $51 \%$ of the total number of enterprises will be able to last only 1 month in quarantine, within 2-3 months $-25 \%, 4-6$ months $-4 \%$ and up to 1 year $1 \%$ [14]. It should be noted that $6 \%$ of the surveyed entrepreneurs have already ceased their activity (as of April). However, in our firm belief, the figure 400 does not correspond to reality. As of August, more than 2.6 million legal entities and indivi-

Table 1

Characteristics of the main indicators of economic development in a pandemic [11]

\begin{tabular}{|l|c|c|c|c|c|c|c|}
\hline \multirow{2}{*}{\multicolumn{1}{|c|}{ Indexes }} & \multicolumn{9}{c|}{ Country } \\
\cline { 2 - 8 } & Ukraine & Spain & France & Germany & EU-28 & USA & United Kingdom \\
\hline Annual GDP growth rate, \% & -11.4 & -22.1 & -18.9 & -11.3 & -14.4 & -9.1 & 1.3 \\
\hline Public debt to GDP, \% & 50.3 & 99.5 & 98.1 & 59.8 & 79.3 & 107.0 & 80.7 \\
\hline Unemployment rate, \% & 8.6 & 15.3 & 7.1 & 4.4 & 7.2 & 8.4 & 3.9 \\
\hline Youth unemployment, \% & $?$ & 41.7 & 19.7 & 5.7 & 14.2 & 18.6 & 12.7 \\
\hline Consumer price index CPI & 99.8 & 104.0 & 105.0 & 106.0 & 105.0 & 260.0 & 108.5 \\
\hline Inflation rate for the year, \% & 2.5 & -0.5 & 0.2 & 0.0 & 0.8 & 1.3 & 1.7 \\
\hline Industrial production, \% & -4.2 & -6.4 & -11.7 & -11.7 & -1.6 & -8.2 & -1.8 \\
\hline Business trust, p.p. & 90.8 & -8.9 & 93.0 & 92.6 & -25.6 & 56.0 & -1.0 \\
\hline Consumer confidence index, p.p. & 66.7 & 49.9 & 94.0 & -1.8 & -15.5 & 74.1 & -27.0 \\
\hline
\end{tabular}

Note: as of the end of June 2020

Table 2

The number of bankrupt enterprises in the world during the lockdown period [11, 12]

\begin{tabular}{|c|c|c|c|c|c|c|c|}
\hline \multirow{2}{*}{ Indexes } & \multicolumn{7}{|c|}{ Country* $^{*}$} \\
\cline { 2 - 9 } & Ukraine $^{* *}$ & Spain & France & Germany & Belgium & USA & United Kingdom \\
\hline Bankruptcy of enterprises, units & 400 & 1111 & 122 & 1354 & 484 & 22482 & 2974 \\
\hline
\end{tabular}

Notes: ${ }^{*}$ - as of the end of June $2020,{ }^{* *}$ - as of the end of August 
dual entrepreneurs were registered. Using the above data, we may conclude that for various reasons, including the signs of bankruptcy, about 156 thousand legal entities and individual entrepreneurs ceased their activities.

International financial and investment rating institutions provide disappointing forecasts for the global economy in the near future, including the International Monetary Fund, S\&P Global Economics and Oxford Economic, Moody's and Fitch (Table 3).

According to these forecasts, in 2020 alone there will be a decline in macroeconomic indicators of world economies. Then there will be gradual economic growth. However, the statements of the WHO President and Bill \& Melinda Gates Foundation that the pandemic will continue for 2 to 5 years are unclear from these positions. Then the question arises for analysts and experts engaged in forecasting: where will the economic boom come from if the quarantine continues? This dilemma is particularly relevant in developing countries, countries with high external debt burdens, virtually destroyed industry and the lowest living standards, i.e. high levels of poverty. Under such conditions, the economy will continue to stagnate and the decline will only deepen, despite the optimistic forecasts of experts. This is confirmed by a survey conducted by the Department of Strategic Planning and Macroeconomic Forecasting [15], according to which $93 \%$ of respondents said that the coronavirus crisis will change the nature of
Table 3

Forecasts of the world economy in terms of Covid-19

\begin{tabular}{|l|c|c|c|}
\hline \multirow{2}{*}{\multicolumn{1}{|c|}{ Name of the institution }} & \multicolumn{3}{c|}{ Years } \\
\cline { 2 - 4 } & 2020 & 2021 & 2022 \\
\hline International Monetary Fund & -3.0 & 5.8 & \\
\hline $\begin{array}{l}\text { S\&P Global Economics and Oxford } \\
\text { Economics }\end{array}$ & -2.4 & 5.9 & 3.9 \\
\hline Moody's (for G20 countries) & -4.6 & 5.3 & \\
\hline Fitch & -4.6 & 4.9 & 3.4 \\
\hline
\end{tabular}

future world economic development, and of course not for the better. In turn, Reinhart [16] predicts the recovery of the world economy to a pre-pandemic level only after 5 years. Thus, the forecasts developed by the leading institutions may be wrong, as the continuation of the pandemic will have catastrophic consequences for national economies and most economic activities.

Consequences for Ukrainian economy. In March of this year, Prime Minister D. Shmygal announced the introduction of quarantine measures, and in late April - announced a stepby-step plan of quarantine emergence divided into 5 stages [17] (Fig. 1).

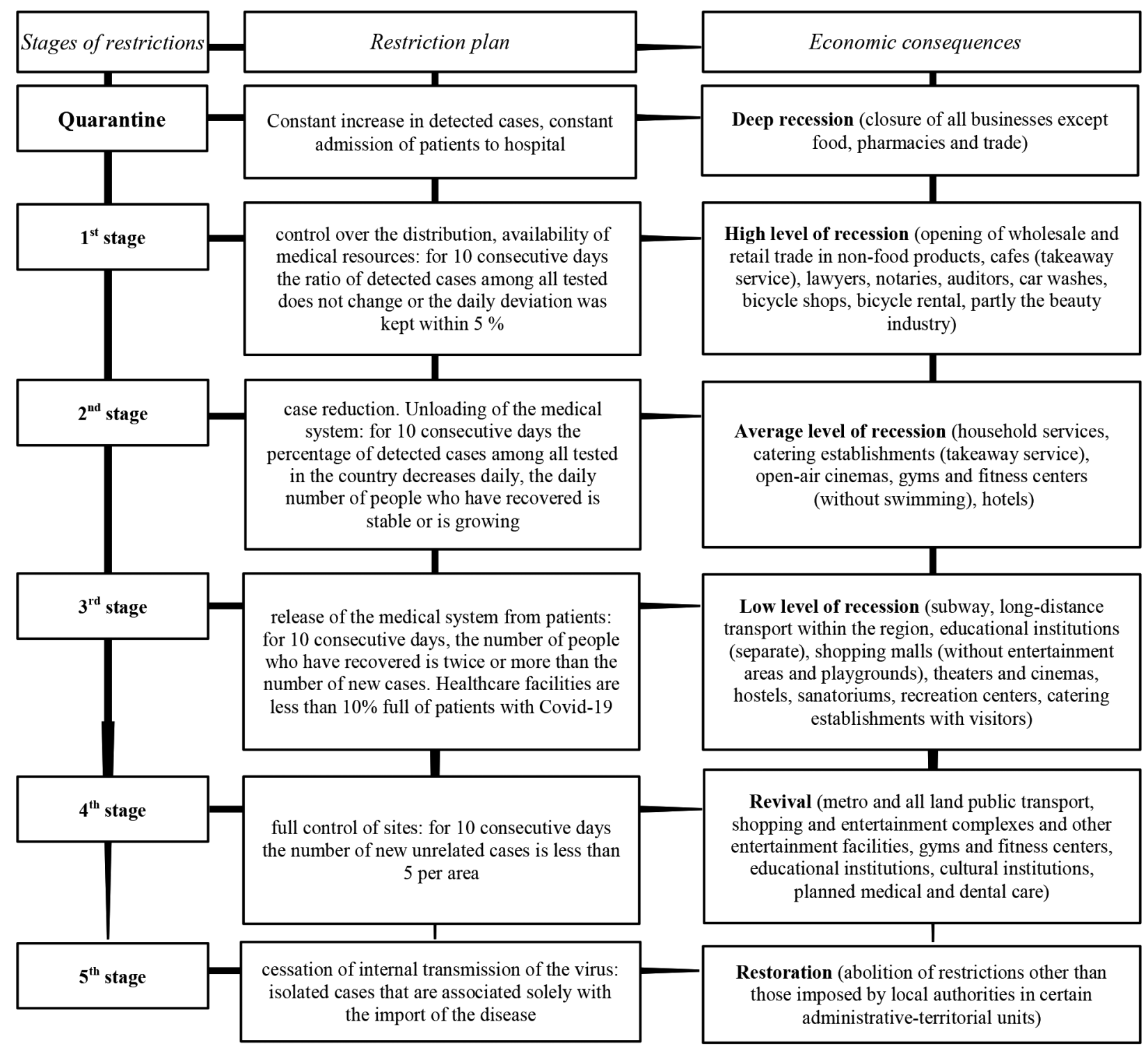

Fig. 1. Quarantine restrictions and economic consequences for economic activities [17] 
With quarantine restrictions, including the first two stages, there comes a recession. A recession is a continuous unstopping decline in economic activity for more than six months.

Under the conditions of quarantine there is a complete closure of all types of business, except for the activities of wholesale and retail trade in food, pharmacies (medicines). Road, rail and air transportation services are suspended both within the country and abroad. Many economic activities are moving to a remote mode of operation, especially in the service sector. There is a huge decline in lease agreements for office space and the bankruptcy of small and micro enterprises, cafeterias serving such offices. Households, for the most part, exist due to their own savings and accumulations, there is a temporary activity cessation of medium and large enterprises. In the future, various types of businesses will be gradually opened and restrictions on their operation will be lifted. There is a temporary or complete dismissal of employees of enterprises from the main place of work, reduced labor productivity and gross output decrease [18].

Regarding Ukraine, IMF analysts provided a disappointing forecast of GDP: in 2020 - a decline of $8.8 \%$, in 2021 - an increase of $1.1 \%$ and in 2022 - an increase of $3 \%$ [19]. It is clear that this trend will negatively affect the economy of the country, on the results of 2020-2022 we will witness a negative trend $(-4.7 \%)$. The EBRD, in turn, provided a more optimistic forecast for the decline of Ukraine's economy at $4.5-5.5 \%$, the NBU recorded a mark of $6 \%$ by the end of 2020 [20]. Under such conditions, with high inflation, rising producer prices and insignificant growth, and sometimes a decrease, of household income, it will be necessary to accumulate credit debt (due to the state budget deficit) to national and external creditors. According to the above study [15], changes in Ukraine are seen by $84 \%$ versus $16 \%$ of those who do not see significant changes in future economic development. Nitsenko adds that the economic downturn could be above $30 \%$, which is directly related to the closure of enterprises, layoffs and increased financing of the state deficit by new borrowing [5].

Kushch notes that the state must take on the enormous burden of post-pandemic economic recovery, especially related to incentives and depreciation measures. He also notes the inadequacy of the existing antiCOVID package of $1.5 \%$ of GDP, while other countries allocate from 10-15\% (in developing economies) to $20-25 \%$ (developed economies) [21].

The unwillingness and lack of relevant competencies of the President and the Government to counter the threat have led to the collapse of the economy and a significant outflow of investment from budget-forming industries (Fig. 2), reducing GDP and the number of operating enterprises (temporary or complete closure). In general, during 2019-2020, the inflow of investments into the economy of Ukraine has decreased by $29 \%$, and into agricultural activity - by $35.3 \%$.

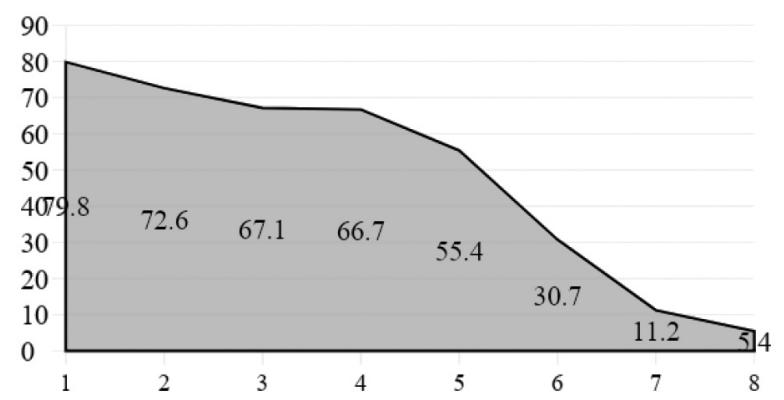

Fig. 2. Reduction of the level of capital investments (investments) in the main economic activities [22]:

1 - Arts, sports, entertainment and recreation; 2 - Research and development; 3 - Forestry and logging; 4 - Sphere of temporary accommodation and catering; 5 - Transport, warehousing, postal and courier activities; 6 - Industry; 7 - Construction; 8-Financial and insurance activities
Thus, there is a continuous decline in the effectiveness of mechanisms for public management of economic processes in the face of a viral threat.

Conclusions. The pandemic effects of Covid-19 coronavirus infection have a destructive effect on the world economy and the economies of countries. As a result of the unpreparedness and lack of effective mechanisms to stop the spread of this threat, many countries have restricted or completely stopped transport within or outside their countries. This problem has a direct impact on the functioning of enterprises and the activity of households. Studies have shown a systematic chain reaction, with the result that many companies have gone bankrupt, a large proportion of employees have been laid off or are on temporary leave at their own expense, labor productivity has fallen, unemployment is rising, and GDP has fallen sharply.

The imposition of severe restrictions on the operation of the business has caused enormous losses and reduced contributions to the budgets of the respective levels. Investments in all sectors of the economy underwent negative changes (5.4$79.8 \%)$.

We conclude about the inability to introduce effective crisis management mechanisms at the state level, which is manifested in the deepening of the systemic crisis, which began at the end of last year. Predicting the negative trends of the world and national economy does not add optimism, neither do the forecasts of international financial and rating organizations which do not coincide with the statements of the heads of the WHO and the Bill \& Melinda Gates Foundation, who predict a prolongation of this crisis over the next $2-5$ years.

\section{References.}

1. Saakov, V. (2020). The NBU expects GDP to fall by five percent in 2020 due to the coronavirus. Deutsche Welle. Retrieved from https://p.dw.com/p/3bJVL.

2. Dumanska, M. (2020). France's GDP fell a record amid the COVID-19 pandemic. Deutsche Welle. Retrieved from https://p.dw.com/p/3bb4M.

3. Ukrinform (2020). Consequences of quarantine for the economy of Ukraine and ways to overcome them. Retrieved from https:// www.ukrinform.ua/rubric-presshall/3034153-naslidki-karantinu-dla-ekonomiki-ukraini-ta-slahi-ihnogo-podolanna.html.

4. Mironenko-Shulgan, O. (2020). Small business in the context of the COVID-19 pandemic: legal regulation of financial support by the state. Retrieved from https://unba.org.ua/publications/ print/5792-malij-biznes-v-umovah-pandemii-covid-19-pravove-regulyuvannya-finansovoi-pidtrimki-derzhavoyu.html. 5. Nitsenko, V. (2020). Mismanagement in Ukraine. Problems of Management in the $21^{\text {st }}$ Century, 15(1), 4-8. https://doi. org/10.33225/pmc/20.15.04

6. Zalizko, V., Nowak, D., \& Kukhta, P. (2020). Economic security of Ukraine: innovative concept of strengthening in the context of COVID-19. Naukovyi Visnyk Natsionalnoho Hirnychoho Universytetu, (4), 152-157. https://doi.org/10.33271/ nvngu/2020-4/152.

7. The U.S. Economic Recession Grows Deeper and Bleaker (July 31, 2020). Stratfor Enterprises. Retrieved from https:// worldview.stratfor.com/article/us-economic-recessiongrows-deeper-and-bleaker.

8. Hawken, A., \& Brown, A. (2020). Budget LIVE: Rishi Sunak unveils $£ 30$ bn coronavirus package and stamp duty hike for overseas buyers. The Sun. Retrieved from https://www.thesun.co.uk/news/politics/11144022/budget-2020-uk-live-rishi-sunak-coronavirus/.

9. The Cabinet of Ministers of Ukraine (2020). On the statement of the Procedure for use of means of fund of fight against an acute respiratory illness of COVID-19 caused by a coronavirus of SARS-CoV-2, and its consequences: Resolution; Procedure from 22.04.2020 No. 302. Retrieved from https://zakon.rada.gov. ua/laws/show/302-2020-\%D0\%BF\#Text.

10. Ministry of Finance of Ukraine (2020). COVID-19 Acute Respiratory Disease Foundation for SARS-CoV-2 Coronavirus 
and Its Consequences. Retrieved from https://mof.gov.ua/uk/ data_and_analytics-433.

11. Macroeconomic statistics by country (2020). Retrieved from https://take-profit.org/statistics/.

12. Bankruptcy in numbers: worse for coronacrisis (2020). Retrieved from https://vn.strichka.com/article/106747183.

13. Centre for Aviation (2020). COVID-19. By the end of May, most world airlines will be bankrupt. Retrieved from https:// centreforaviation.com/analysis/reports/covid-19-by-theend-of-may-most-world-airlines-will-be-bankrupt-517512.

14. $51 \%$ of enterprises in quarantine conditions are able to last only 1 month - survey (2020). Ekonomichna pravda. Retrieved from https://www.epravda.com.ua/news/2020/04/2/658865/. 15. Ministry of Economic Development, Trade and Agriculture of Ukraine (2020). The impact of COVID-19 on the economy and society - post-pandemic development. Consensus forecast No. 52. Retrieved from https://www.me.gov.ua/Documents/ Download?id=2b0d350d-a9e5-449a-95cf-fe6cdeaff070.

16. Reuters (2020). Global economic recovery may take five years, World Bank chief economist says. Retrieved from https:// www.reuters.com/article/us-health-coronavirus-worldbank/ global-economic-recovery-may-take-five-years-world-bankchief-economist-says-idUSKBN26816L? $\mathrm{il}=0$.

17. Government portal (2020). Prime Minister Denis Shmygal presented a phased plan to lift restrictions. Retrieved from https://www.kmu.gov.ua/news/premyer-ministr-denis-shmigal-predstaviv-poetapnij-plan-znyattya-obmezhen.

18. Olejarz, T., Nitsenko, V., Chukurna, O., \& Mykhailova, M. (2018). Evaluation of factors influencing labour performance of machine-building enterprises in mining industry. Naukovyi Visnyk Natsionalnoho Hirnychoho Universytetu, (1), 154-162. https://doi.org/10.29202/nvngu/2018-1/2.

19. LIGABusinessInform (2020). The IMF has downgraded the forecast for Ukraine's GDP to fall in 2020. Retrieved from https://ua-news.liga.net/economics/news/mvf-pogirshivprognoz-padinnya-vvp-ukraini-v-2020-rotsi.

20. Ukrinform (2020). The economic decline in Ukraine is not critical - EBRD. Retrieved from https://www.ukrinform.ru/ rubric-economy/3105891-padenie-ekonomiki-v-ukraine-neavlaetsa-kriticeskim-ebrr.html.

21. Ukrinform (2020). In post-quarantine economic realities, $a$ synergy between the government and the central bank is neededan expert. Retrieved from https://www.ukrinform.ua/rubricato/3034948-minreintegracii-zaava-okupantiv-pro-povnubojovu-gotovnist-gra-v-informacijnomu-poli.html.

22. Ukrinform (2020). Experts report a reduction in investment in Ukraine's economy. Retrieved from https://www.ukrinform. ua/rubric-economy/3034670-eksperti-povidomlaut-proskorocenna-investicij-v-ekonomiku-ukraini.html.

\section{Комплексна оцінка економічних наслідків пандемії Covid-19}

\section{С. В. Сімак ${ }^{1}$ Ю. В.Давидюк ${ }^{2}$, Н. М. Бурдейна ${ }^{3}$

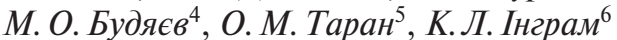

1 - Таврійський національний університет імені В. І. Вернадського, м. Київ, Україна, e-mail: sergii.simak@gmail. com

2 - Державний університет «Житомирська політехніка», м. Житомир, Україна

3 - Військова академія, м. Одеса, Україна

4 - Київський національний економічний університет імені Вадима Гетьмана, м. Київ, Україна

5 - Харківський національний аграрний університет імені В.В. Докучаєва, м. Харків, Україна

6 - Університет Миколя Ромеріса, м. Вільнюс, Литва

Мета. Проаналізувати та узагальнити окремі аспекти негативного прояву коронавірусної інфекції Covid-19 i дати комплексну оцінку наслідків пандемії на світову економіку та економіку України, зокрема.

Методика. У процесі дослідження застосована комплексна аналітична оцінка наслідків впливу пандемії на функціонування світової економіки, що заснована на звітах і прогностичних оцінках відомих учених і фахівців, міжнародних фінансових і кредитно-рейтингових організацій, а також особистих спостережень авторів.

Результати. Отримані результати свідчать про загострення економічної ситуації у світі та в Україні, зокрема. За нетривалий час (півроку) відбулося зниження світового ВВП майже на $4 \%$, а в таких країнах-драйверах, як США - на 9,1 \%, ЕС - на 14,4 \%, Україні - на 11,4 \%. Це $є$ свідченням падінням обсягів промислового виробництва, зниження продуктивності праці, банкрутства й ліквідації малих, мікропідприємств та ФОП, зниження доходів домогосподарств і зростання рівня безробіття. Виникає ситуація, коли уряди країн орієнтуються не на розвиток внутрішнього ринку, а збільшують обсяги кредитних ресурсів, узятих для покриття дефіциту балансу. Стимулюючі заходи, запроваджені у більшості країн світу 3 метою підтримки бізнес-середовища й населення країн, показують, що даний рівень сягає 10-25\% ВВП. У той же час в Україні сформований фонд становив усього 1,5\%, що явно недостатньо. Запровадження жорстких обмежень в Україні у 5 етапів призвели до згортання діяльності багатьох підприємств малого бізнесу та ФОП, через що знижуються надходження до бюджетів різних рівнів. Так, найбільше постраждали від карантинних заходів сфера мистецтва, спорту, розваг і відпочинку (падіння доходів майже на $80 \%$ ), наукових досліджень і розробки (на $73 \%$ ), лісового господарства й лісозаготівлі (на 67 \%), найменше - фінансова та страхова діяльність (усього $5,4 \%)$. Таким чином, розроблені пронози провідними міжнародними та кредитно-рейтинговими інституціями свідчать про невтішні наслідки для світової економіки до кінця 2020 р., після почнеться поступова відлига. Однак, не зрозуміло, яким чином відбуватиметься економічне пожвавлення, якщо карантинні заходи продовжуватимуться й надалі. Це може бути свідченням хибності прогнозів і поглибленням рецесії світової економіки.

Наукова новизна. Нами запропоновано проводити комплексний аналіз головних показників стану й розвитку економічної ситуації з використанням наступних індикаторів: річний темп зростання ВВП, державний борг до ВВП, рівень безробіття, індекс споживчих цін, рівень інфляції за рік, промислове виробництво, ділова довіра та індекс довіри споживачів. Сукупність наведених індикаторів відображає тенденцію розвитку економіки країн в умовах кризової ситуації.

Практична значимість. Наведена методика може бути застосовувана фахівцями Міністерства розвитку економіки, торгівлі й сільського господарства України, науково-дослідними установами та інститутами, окремими вченими в якості основи моніторингу ситуації у країні й регіонах в умовах економічної кризи.

Ключові слова: світова економіка, економіка України, карантинні заходи, пандемія Covid-19, економічні наслідки, рецесія

\section{Комплексная оценка экономических последствий пандемии Covid-19}

\section{С. В. Симак ${ }^{1}$ Ю. В.Давидюк ${ }^{2}$, Н. Н. Бурдейная ${ }^{3}$, М.А.Будяев ${ }^{4}$, О.Н. Таран ${ }^{5}$, К. Л. Инграм ${ }^{6}$}

1 - Таврический национальный университет имени В.И. Вернадского, г. Киев, Украина, e-mail: sergii.simak@ gmail.com

2 - Государственный университет «Житомирская политехника», г. Житомир, Украина 
3 - Военная академия, г. Одесса, Украина

4 - Киевский национальный экономический университет имени Вадима Гетьмана, г. Киев, Украина

5 - Харьковский национальный аграрный университет имени В.В. Докучаева, г. Харьков, Украина

6 - Университет Миколаса Ромериса, г. Вильнюс, Литва

Цель. Проанализировать и обобщить отдельные аспекты негативного проявления коронавирусной инфекции Covid-19 и дать комплексную оценку последствий пандемии на мировую экономику и экономику Украины в частности.

Методика. В процессе исследования применена комплексная аналитическая оценка последствий воздействия пандемии на функционирование мировой экономики, основанная на отчетах и прогностических оценках известных ученых и специалистов, международных финансовых и кредитно-рейтинговых организаций, а также личных наблюдений авторов.

Результаты. Полученные результаты свидетельствуют об обострении экономической ситуации в мире и в Украине, в частности. За непродолжительное время (полгода) произошло снижение мирового ВВП почти на $4 \%$, а в таких странах-драйверах, как США - на 9,1\%, ЕС - на $14,4 \%$, Украине - на 11,4\%. Это является свидетельством падения объемов промышленного производства, снижения производительности труда, банкротства и ликвидации малых, микропредприятий и ФЛП, снижения доходов домохозяйств и роста уровня безработицы. Возникает ситуация, когда правительства стран ориентируются не на развитие внутреннего рынка, а увеличивают объемы кредитных ресурсов, взятых для покрытия дефицита баланса. Стимулирующие меры, введенные в большинстве стран мира с целью поддержки бизнес-среды и населения этих стран, показывают, что данный уровень достигает 10-25 \% ВВП. В то же время в Украине сформированный фонд составлял всего $1,5 \%$, что явно недостаточно. Введение жестких ограничений в Украине в 5 этапов привело к свертыванию деятельности многих предприятий мало- го бизнеса и ФЛП, отчего снижаются поступления в бюджеты различных уровней. Так, больше всего пострадали от карантинных мероприятий сфера искусства, спорта, развлечений и отдыха (падение доходов почти на $80 \%$ ), научных исследований и разработки (на $73 \%$ ), лесного хозяйства и лесозаготовки (на $67 \%$ ), меньше всего - финансовая и страховая деятельность (всего 5,4\%). Таким образом, разработанные прогнозы ведущими международными и кредитно-рейтинговыми организациями свидетельствуют о неутешительных последствиях для мировой экономики до конца 2020 г. После начнется постепенная оттепель. Однако, не понятно, каким образом будет происходить экономическое оживление, если карантинные мероприятия будут продолжаться и в дальнейшем. Это может быть свидетельством ошибочности прогнозов и углублением рецессии мировой экономики.

Научная новизна. Нами предложено проводить комплексный анализ главных показателей состояния и развития экономической ситуации с использованием следующих индикаторов: годовой темп роста ВВП, государственный долг к ВВП, уровень безработицы, индекс потребительских цен, уровень инфляции за год, промышленное производство, деловое доверие и индекс доверия потребителей. Совокупность приведенных индикаторов отражает тенденцию развития экономики стран в условиях кризисной ситуации.

Практическая значимость. Приведенная методика может быть применена специалистами Министерства развития экономики, торговли и сельского хозяйства Украины, научно-исследовательскими учреждениями и институтами, отдельными учеными в качестве основы мониторинга ситуации в стране и регионах в условиях экономического кризиса.

Ключевые слова: мировая экономика, экономика Украины, карантинные мероприятия, пандемия Covid-19, экономические последствия, рецессия

Recommended for publication by O.M. Halytskyi, Doctor of Economic Sciences. The manuscript was submitted 12.05.20. 